\title{
On the Nature of Politics: A Critical Analysis
}

\author{
Patrick Neil M. Santiago
}

\begin{abstract}
Absurdity occurs when demagogues deliberately abuse their power inflicted by their own interest and self-gratification over giving service to humanity and fulfilling social obligations. At present, most political leaders make improper practices of politics. This paper investigates the basis why primitive man needs to engage in a social contract, emancipated from a chain, the nature of democracy, filth on participatory democracy, check and balanced of a certain state, and restore the harmony of such state to affirm the present condition of absurdity. Participatory democracy is found as the most corrupt form of government. Hence, most political leaders greedily exercise their powers. This is totally absurd. It is said then that the will of man dominates over his reason.
\end{abstract}

Keyword-absurdity, democracy, politics, reason, will.

\section{INTRODUCTION}

In its narrowest sense, politics is the art and science of good governance. The political development takes a long period but is tragic in nature due to the different perspectives of those who are in it. It motivates evilness over virtue through the savage instinct of man to rule and to lead. Politics becomes dangerous and filthy living in which leaders abuse their sovereignty to torture people in the community.

Politics is part of man's nature and moving bodies of this physical world. It exists for the purposes of good leadership and governance in order to subjugate a harmonious state. However, in the present condition, it exists to inspire vices and promote common interests. Ultimately, nobody lives alone or on his own. Under these circumstances, no one can hide or avoid the savage instinct and cruelty of mankind.

\section{A. Hobbes' Social Contract}

In the classical era, Greek philosophers fostered the collaboration of man within the state. In medieval times they considered the significance of religion specifically Christianity. On the other hand, great thinkers in the modern period preferred to look between the individual and the state.

The English philosopher Thomas Hobbes (15881679) postulates his theory of state from his vantage point of logical and analytical approach rather than historical. He prefers to use a mechanical process to explain the cause of the state inspired by the motion of bodies. He resembles the mathematical method-geometry that deduces self-evident arguments inferring the cluster to human nature.
The state of nature as described by Hobbes in his book Leviathan exhibits that the life of man was solitary, poor, nasty, brutish and short (Hobbes, 1996). The condition of human nature in the primitive state could picture the savage instinct and harsh nature of man. This is simply because a man was born with equal freedom and has equal rights that he can exercise whatever he takes in doing so. There's no such set of morality regarded virtue or justice, thus no compulsory obligation to do something with due respect to people as a whole. Certain law of nature is a precept. This connotes what is morally upright and what is morally unacceptable (Hobbes, 1996). People tend to be governed by their own will and reason. The motivation that man possesses gives him a chance to survive and save his life from a violent death (Hobbes, 1996).

Human nature sets no rules but man moves through natural law which relentlessly pursues his survival. This resembles Herbert Spencer's (1820-1903) theory of sociocultural evolution that underscores the concept of "survival of the fittest", the strong shall only live and the weak will die. Apparently, the fundamental law of nature ought to seek peace and follow it (Hobbes, 1996). This shows that by all means, the man defends himself. The good and evil forces signify to man's appetites and aversions (Hobbes, 1996). The goodness for savage man is derived from his own selfish will which is called appetite and the evil curses for the wrath on the enemy. This pictures an anarchic state of humanity that drives in a horrible condition as seen by Hobbes.

The natural law impels to seek peace in which the major vantage point is survival. Hobbes had seen the logical 
consequences that will avoid an anarchic state of nature towards the ultimate way to survive. He offered the need to enter a social contract that resolved the severe conflict of individual and egotism that caused political problems. The anarchic state of nature renounces some individual rights into an artificial person which is called leviathan, the state or commonwealth. Hence, the sovereign is the sum of the individuals. No one could resist or else it would break the agreement and be illogical.

A social contract refers to an agreement of each individual to govern themselves by the sovereign. Sovereignty is an abstract representation of a single ruler that has absolute power over the people. Hence, the natural individual right from the anarchic state of nature will then transfer to the sovereign to rule people who constitute the general will. The absolute power of the sovereign occurs to be responsible for the security and welfare of the people to execute peace and order that serve as political obligations.

\section{B. Rousseau's on Liberty and Equality}

The French philosopher, Jean-Jacques Rousseau (1712-1778) made a contribution through his writings that enlightened the people of his time. He emphasized feeling over reason is the basis of politics. In his book The Social Contract, he begins his famous statements by saying, "Man is born free; and everywhere he is in chains" (Rousseau, 2002). Here, he emphasized liberty and equality in a society that when exercised, people would be freed from the chains and shackles of oppression thereby achieving freedom. Rousseau realized that the primitive man fettered again in society through the Social Contract.

In the state of nature man had been motivated by natural sentiments through self-preservation called survival. On the other hand, as people invented social contract, a man was motivated by an artificial sentiment that led him to compel more than others. In effect, it resulted in an intense competition against each other that triggered vices towards evilness.

From this contradictory condition, how do people reconcile to achieve total independence? Rousseau suggested finding a form of association that may depend and protect the whole force of the community for each person and property. The social pact is Rousseau's solution to resolve complex conditions. Like Hobbes in terms of his political theory, Rousseau did not look at the contract in historical terms for he believed that social contract was a living reality. To some extent, the aim of Rousseau is to supplement an answer on why people ought to obey the laws of the government. This purpose is to harmonize and achieve real freedom from others. This freedom remained a chain through a social contract.

Rousseau postulates that what man loses through social contract is his natural liberty and an unlimited right to anything that tempts him to attain; what he gains is civil liberty and property in all that he possesses. The rights of every individual that are being transferred to the sovereign embodied the general will, thus, it is indivisible as a whole. Hence, if one renounces to obey this general will, then he will compel to do so. This system seems that every individual is governed by a certain chain of control.

Rousseau's concern is about the general will in which accordingly man is forced to be free. At this point he tends to attack this context that intends to emerge into the will of all. Apparently, a general will and will of all seem related in their purpose for common good. But if the purpose is opposed to the common good which concerns private or especial interest then this does not express as general will. As Rousseau implies general will and will of all are different, the general will is always right and always tends for the public good. On the contrary, the will of all is preferably collective consensuses or divided disagreements. This is simply participatory exercise through the votation of individuals which is an abstract expression of what is the best for all citizens. Since laws are a product of general will, thus an individual is accountable or entitled to decisions of approval.

Rousseau believed that the consent of citizens to the common good is the most possible path to obtain the social equality and real freedom of citizens. Under the law of private opinion that prevailed, or without conformity, people were forced to behave in accordance with imposed law. This law should be made under the common good or justice that overcomes the personal interest or factions of will. Everyone should be involved and entitled to the decision of lawmaking. Each citizen is allowed to exercise total freedom. Thus, when man's right of suffrage is impeded and when his liberty is taken away, he is forced to rectify the system to achieve freedom.

Rousseau's political theory serves a major turning point in the Enlightenment period and considers him as the trailblazer of the romantic sensibility that spread in Europe. The aristocracy form of government adopted Rousseau's primitivism playing at the back to nature which elevated the country's life and further alienated the upper class from the 
average Frenchman. Finally, the masses took Rousseau's ideas of total participatory which is in a form of democracy.

\section{Aristotle's Nature of Government}

The famous Greek philosopher, Aristotle (384-322 BCE) made a great contribution to our present concept about politics which evidently affirms his product in the figure of his student, Alexander the Great. Aristotle developed a system of classifying government in the fourth century BCE showing its different forms. For him the true forms are Monarchy (one), Aristocracy (few), and Polity (many). Whereas the perverted forms are: Tyranny (one), Oligarchy (few), Democracy (many) (Barnes. 1984). Aristotle's preference among them is aristocratic form because for him it has an aberrant degree of excellence that is responsible and capable of political command and governance (Barnes, 1984).

Aristotle also emphasized that the democratic form of government is the most corrupt of all classified systems where it ruled in favor of the interest of the rulers. Diana J. Mendoza, et.al, (1999) emphasized that "deluded into thinking that one person is as good as another, the masses in a democracy blindly follow the lead of corrupt and selfish demagogues who plunder the property of the hardworking and the capable". This affirms that democracy can be considered as the worse form of government that acts only to further its own selfish interests.

In addition, Lydia Yu-Jose, et.al. (1999) espoused that wars may be the cause or the result of politics, but she stressed that the two are not the same. She explained that "war is the death or failure of politics". Through it, chaos becomes more evident in the community. People get greedy of power and position; and become guilty and filthy of corruption and fraudulence. In retrospect to Hobbes concerning the general rule-natural law, it explicitly affirms that man's principal aim is self-preservation through seeking a peaceful and ordered society. In this regard, man needs to create the so-called social contract. He will enter an agreement between each individual to express the general will. If that therefore, failed to comply in doing so, then that fall to Yu-Jose's war -the death or failure of politics.

Aristotle's main point pictured out the scenario of a good form of government that flows into failure due to the corrupt interest of the ruler. Politics also showed a transition through generation. The government evolved from a monarchy to democracy, and the noble ruler transformed from being monarch to democratic people-centered governance.
Politics emancipate through many generations and surpasses in the many aspects of life's transition such as morality, nobleness and slavery that come from different shapes of life from fine arts to mass art; and even religion from primitive beliefs to recent Christianity.

This paper addresses the concerns on: What is the nature of politics? What is the role and motivation of politics in the state? What is the present condition of politics? Who is involved in the initiative? What is the solution to having a disharmonious state?

\section{METHODOLOGY}

This study utilized a critical analysis method of understanding, analyzing and synthesizing issues about politics to explore and affirm its present notions, facets and effects to humanity. This method was adopted by J.L. Beyer. According to [5] as cited by Santiago (2019) "critical analysis is subjective writing because it expresses the writer's opinion or evaluation of a text which was broken down into parts". The chief intent of this inquiry is to identify and explain the problem on the present condition of politics that appears absurd and to provide substantial insights, inspirations and illumination to its readers.

\section{ANALYSIS AND EVALUATION}

\section{A. Participatory Democracy}

Today, democracy is the most practiced form of government by many countries. This serves as a new beginning for man to revive the long stagnation of his society is decaying and depleting the state of his society to taste the savor of progress and growth. The forgetfulness from the long endures of a camel to a newborn child gives emancipating chance to thrive.

Etymologically, the word democracy comes from the Greek word "demokratia" which means government for the people. Similarly, "Demos" means people and "kratia" means government. Aristotle described democracy in which the many and the poor are the rulers (Barnes, 1984).

The interests of man grew from the deepest desire of the one who rules and makes him a god of his own will and subordinates. This alluding phenomenon happens to a tribe when it gets its power. In a tribe, man always pays homage to its ancestors, offering sacrifices to them as an expression of 
gratitude to them. As the power of the tribe grows, the need to offer such sacrifice and honor to the ruling ancestors gets larger and greater. As these ancestors gain power, the more they throne themselves as gods. This voracious intent exists in-different places, organizations, and institutions in a community. Politicians fabricated some prominent programs and promising propagandas to capture the heart of the people. They have situated programs like medical missions, educational financial assistance, scholarships program, feeding program and other charity works that suggest heroic actions for the victims of calamity and natural disasters. Such compassionate actions project showmanship and forged effort to exhibit concern for others. However, these actions were documented, named and published in newspapers or magazines to highlight people over service. The German philosopher Friedrich Nietzsche (1844-1900) stressed in his writings "don't name your virtue" (Nietzsche, 1969). The true endeavor or genuine love of man should not be in such scripted doings while bragging one's deed at the expense of public funds. Majority of the politicians today wear the artificial instrument of concern and caring blankets to convince individuals of their blossoming scents attached to their names, so people would see them as responsible and untainted leaders, not knowing that they only used the funds or budget of government for their projects and other purposes for them to become popular and gain power.

The absurdity of the above scenario is a clear depiction of coveted funds that were taken from the levy funds of the citizens and misused by many politicians. They rule the community using such funds. These politicians amaze people through their piling up accomplishments that originally come from their own labor and sacrifices. These political beasts who are gluttonous of power and fame claim success and visible inventions, progress and growth. This absurdity is coated with a virtue of politicians to do good with the intent of evil. They fascinate people so that they treat them as gods. Ordinary people are not aware of these doings particularly the wealth stolen by these politicians. In reality, the majority of these beasts allocate very little budget for projects and needs of the community and the entity of it goes to their accounts. This act is committed as if it is a natural system that originates from the bureaucratic practice of the past. A practice that is enjoyed by many beasts to sustain their power and survive the filthy system of habitat they must conform.

In a public administration class who was composed of public employees and public officials, they tackled some political issues that are observed in our society today. They clarified and agreed that politician's immediate aim to win for the election is greatly influenced by his personal desire to gain many perks in the government. As the discussion progressed, students arrived at the concluding situation that the concern for social development and personal involvement of a leader to his citizen is a mere political strategy for the people to become indebted and slaves through their "Utang na Loob", and so he still gets the position he desires. In this discussion, students made a comparison between a leader who worked for a sincere development of his territory but seldom appeared to his people and a leader who worked directly and intently and was visibly seen by his people. One may wonder why a leader's accomplishment must be always highlighted; why is it that in most of the gatherings, programs and affairs in the community, they deliver flowery and long speeches which bore the ears of the audience. "Utang na loob" is the name of the game! To them, they believe that by letting people see their rising accomplishments, the more they get anchored and amazed, the more they tend to support in for the next terms. Indeed, this scenario has blinded the eyes of many civilians.

The example above is close to the concept of predator and prey. The bait is a substance that easily captures the prey. The hidden content of filth in the legacy of a fraud leader that creates a strong instrument for his triumph. It is a painful reality to feel that this political scenario seems unresolvable whether the community likes it or not they should accept the fact that it is real and that is part of the game. Politicians such as barangay captains, councilors, mayors, governors, congressmen and even those with higher ranks vow to religious leaders. Imagine how the untouchable, sophisticated and powerful politicians vow to an ordinary religious leader. These politicians offer homage, monetary offerings and gifts and other material things in order to earn the support of the religious organization for them to win in the election. Power and justice are compromised in exchange for the assurance to win and remain in the position they hold and coveted. Such act obviously shows how their divine virtue turns into devilish vow just to sustain power, and this is precisely the means in order to transform themselves into a "god" in their community.

While politics remains the science of governance as it demands a more comprehensible and sound platform to impact change in the community, initiate progress and achieve sustainability, the nature of politics constituted with positive and negative impressions and the one who is supposed to be very responsible to create such impacts is in the total distortion of absurdity. 
Aristotle viewed that there are rulers who seek their power to rule others solely to serve their own interests of the ruled (Barnes, 1984). From here Yu-Jose clarified the distinction between politicians and statesmen. The concept of a statesman relates to a person whose main preoccupation is the betterment of the state and governs the society productively (Yu-Jose, et.al.1999). On the other hand, politicians are those who place their personal affairs and interests above the concerns of the state. She concluded that not all politicians are statesmen.

This exhibits that the nature of politics occurs to be severe. The present condition on participatory democracy explicitly reflected in Aristotle's notion of perversion. He might be right at some points of his arguments that democracy is the most corrupt form. Most leaders of the democratic form do not comply to fulfill their social obligations but rather enjoy sovereignty like building reputable names and positions in the government service. This appears that most leaders centered on their needs to subjugate and control people instead of pursuing the thrust of excellence towards justice and peace.

In clarification of the concept of politics, it is absolutely not asserted to negate its essence or give flawed remarks on it; however, as reflected in the writings of Lydia $\mathrm{N}$. Yu-Jose stating that "the complaint of too much politics is not a protest against the nature of politics, but a demand for the proper practice of politics" (Yu-Jose, et.al.1999). Politics may inevitably be encountered or practiced in this physical world. Bad conscience, the sadistic instinct of man, and improper practices on politics are just a few frightening and threatening things that lead to mismanagement, misconception and misapplication of the science and art of politics. Moreover, the illness of society seems unending. Yes, the issues and problems in politics remain irresolvable. It has become cancer in a rotting body of this motherland. Nevertheless, it is continuously circulating like the blood that runs in the deepest veins of man's absurdity.

\section{B. Check and Balance on State}

We are all aware that democracy has three branches such as legislative, executive and judiciary. Each of the branches cited evaluates its counterpart that serves as the check-and-balance methodology. Focusing on the governance, the state with a democratic form of government utilizes civil law as its foundation. In this regard, the constitution serves as its bible to execute civil law which every citizen must follow.
The government is regarded as the sovereign body ruling the state but it is not only accountable for the holistic initiative of a certain state. The English philosopher John Locke (1632-1704) is said to be the descendant of Hobbes, who deeply influenced his political theory and contributed major interest to individual liberty. Locke classified the three basic laws - Divine law, Civil law, and Public Opinion or Community law (Locke, 1999). Hence, this clearly exhibits that the government is just one of the three existing elements that constitute a state. In this regard, the three existing elements involved in a certain state include the Government, the Church and the Public.

The constitution or civil law has an existing course of action that inevitably considers the interference of what they think illogical. Civil law judge whether it is a crime or innocence. The church opposes this civil law for the reason of delving against the maxims of Ten Commandments. By submitting to this bylaw will oppose the precepts of the Bible. The Divine law judge whether it is a sin or duties. The sentiment of the majority particularly the Filipinos on the political and religious act has gained strong consideration from the public opinions known as community law. The public opinions judge whether it is a virtue or vice. These three elements are to be likened to Government, the Church and the Public. Civil law, divine law and community law maintain harmony and balance irregularities in the pinnacle of the political world.

\section{The Apollonian and Dionysian Approach}

It is worthy of pondering what is the best way to restore the harmony between politics and the community. Nietzsche suggested his formula to cure this cancer in the society that is by applying the Apollonian and Dionysian approach. Nietzsche expresses in his book, The Birth of Tragedy; Apollo is characterized as rational, logical, restrained ruler, while in contrast, Dionysus is characterized as irrational, emotional, chaos, and villain (Nietzsche, 1995). The Apollonian and Dionysian approaches resemble the Chinese element of Yin and Yang. These two elements are significant spirits that balance political circumstances and irregularities that could harm the flow of life. With these approaches in politics, one can hope to retain the harmony of life particularly in governance. For instance, if Apollo as a form of government is abusing its power, perverting its advantages and exercising oppressions, then there is Dionysus to form public opinion, a new people's army that will balance 
such irregularities. With the power that Dionysus can do to balance the scale of aberration, all the threats and jeopardies that Apollo can bring will be stopped and so harmony can be achieved and retained. For more concrete understanding, an example of this kind is the dictatorial government of Ferdinand Marcos. History pronounced that the system and governance of the former president were truly remarkable; however, as Aristotle emphasized, when personal interest flow to its abusive will, one will be led to be corrupt in form. From this example of dictatorial government characterized the Apollonian form and the Dionysian form through the public opinion that enraged EDSA revolt. The two elements complement each other to balance the harmony of the state.

\section{SUMMARY AND CONCLUSION}

This paper expounded issues on politics. In the first discussion, Hobbes described the anarchic state of nature in which the condition is the state of "war of all against all". This conflict of the primitive man is seen intended for the very aim self-preservation-survival. Through this, Hobbes had seen the possible solution to resolve complex conflicts by deducing the most possible ought of primitive man. He postulates that the first and fundamental law of nature ought to seek peace and follow it. Thus, he suggested that man should be in agreement with a social contract. This contract was the right of everyone to transfer, to rule people and to govern themselves. No one can break, make rebel action or else it will be considered illogical.

Rousseau had seen that man remains in the chain. In this instance, Rousseau realized that man needed to go back to nature where each individual had an unlimited right. He utilized general will; emerged this into the will of allparticipatory that expressed the most general will. Since the law is the product of general will, then the ground law as its foundation will govern each individual itself. Through this, each citizen can achieve liberty and social equality, thus, by law he is then in a chain. Rousseau's political theory then serves a major turning point in the Enlightenment period and considers him as the trailblazer of the romantic sensibility that spread in Europe. Consequently, the masses took Rousseau's ideas of total participatory- democracy.

In retrospection to Aristotle's treatise on politics which affirms that democracy is the worst classified form of government, he emphasized that in a democratic form of government, the most corrupt rule is in favor of the interest of the rulers. For some reason the demagogues subjugate but act only to further their own personal interest rather than think into excellence and justice. The present condition on participatory democracy exhibits that the demagogues capture the hearth of the masses by their hidden filth. Most of them concealed in their pretentious masks that are perceived as forms of virtue. People idolized those political leaders and consider them as models of society. But the worst effect is they transfigured themselves as gods in their community. Apparently, what is clear is that they play into the masses; they exist for political survival rather than fulfill the social obligation. Hence, two factors give an impact on man's life his very nature and his environment. The question remains unanswered- where these factors have been instigated? Man longs for power, pride, prestige, position, privilege and possessions. His longings for such pleasures gave irrevocable urge to gain such gratifications. From this vantage point, it is with a strong assertion that man's endeavors are deeply rooted in one basic element that is common to all- love. It is a universal instinct, an abstract thought but with a concrete concept. Love exists without any posit objects or necessary predicates, an unfathomable occurrence, a complex affection that has rational and irrational foundations- appetite.

The three elements involved in the initiative of a certain state served as a check and balance mechanisms. As classified by Locke, the three laws are to be likened to Government, the Church and the Public. These three elements interact with each other that results to configure what is best for all citizens.

Since we cannot avoid or eliminate the inevitable irregularities, harmful or dangerous in a certain state, we found that the formula of Nietzsche's Apollonian and Dionysian approach is the best antidote to cure the said irregularities or cancer of the society. In this regard, if the masses could see the abusive demagogues that cause harm or danger among the living, then the masses can subjugate in accordance with their opinion. In reverse, if the masses are seen uncontrollable to their will and rights that caused to the same danger, then the sovereign can fully force to control or implement martial law. Within these two elements we had seen how a certain state could restore its harmonious Commonwealth.

It is concluded that participatory democracy is found as the most corrupted form of government. The present condition falls in the conclusion that most political leaders make improper practices of politics which we found absurd. Indeed, politics is designed to achieve peace and order in a certain state to express general will and to enlarge the 
sovereign place for freedom and progress. After all, it makes sense to say that the will dominates over reason. It is therefore advocated that politicians need to be proficient leaders (Salangsang \& Subia, 2020) and improve their higher-order thinking skills (Subia, et.al., 2020) and enhance their political will for their people and nations to succeed.

\section{ACKNOWLEDGEMENTS}

In his utmost gratitude the author wishes to acknowledge with profound gratitude his wife Nenita and his daughters: Sophia and Athena as well as his father Orestes and his brother Ronald who always serve as his inspiration in life's undertaking and take care of him especially in his dark and challenging times.

In the course of this work, the author expresses his affectionate appreciation to his friend, Dr. Ronaldo R. Larioque for his substantial contribution, willingness in giving his time and effort and for constructively critiquing his work and offering his insightful comments and suggestion.

\section{REFERENCES}

[1] Hobbes, Thomas. Leviathan, ed. with an intro. and notes J.C.A. Gaskin, New York: Oxford University Press Inc., 1996.

[2] Rousseau, Jean-Jacques. The Social Contract and The First and Second Discourses, ed., with an intro, Susan Dunn, New York: Yale University Press, 2002.

[3] Barnes, Jonathan. ed., The Complete Works of Aristotle: Politics, Princeton, NJ: Princeton University Press, 1984.

[4] Yu- Jose, Lydia N., Diana J. Mendoza, Marlon J. Manuel, Alma Ocampo-Salvador, Rodelio C. Manacsa, Ma. Lourdes F. Melegrito, Ma. Elissa R. Jayme, Politics and Governance: Theory and Practice in the Philippine Context, Quezon City: Ateneo De Manila Press, 1999.

[5] Critical Analysis https://www2.southeastern.edu/Academics/Faculty/elejeune/cri tique.htm.

[6] Santiago, Patrick Neil. On the Basis of Love: A Critical Analysis. American Journal of Humanities and Social Sciences Research (AJHSSR) e-ISSN : 2378-703X Volume-3, Issue-7, pp-34-40, 2019.

[7] Nietzsche, Friedrich. Thus Spoke Zarathustra, trans. with an intro., R. J. Hollingdale, England: Penguin Books Ltd., 1961, 1969.

[8] Locke, John. An Essay Concerning Human Understanding, Pennsylvania, PA: State University Press, 1999.

[9] Nietzsche, Friedrich. The Birth of Tragedy, trans. by Clifton P. Fadiman, New York: Dover Publication, Inc., 1995.
[10] Salangsang, L. \& Subia, G. Mathematical Thinking On Problem Solving and Self-Regulation Strategies of Filipino Primary Grade Pupils.International Journal of Scientific \& Technology Research. Volume 9, Issue 02, February 2020, ISSN 2277-8616.

[11] Subia,G., et.al.Cognitive Levels as Measure of Higher-Order Thinking Skills in Senior High School Mathematics of Science, Technology, Engineering and Mathematics (STEM) Graduates. Technology Reports of Kansai University. Volume 62, Issue 03, April, 2020,ISSN: 04532198. 